\title{
Protein kinase A translocation and insulin secretion in pancreatic $\beta$-cells: studies with adenylate cyclase toxin from Bordetella pertussis
}

\author{
Zhiyong GA0*†, Robert A. YOUNG*, Matteo M. TRUCCO*, Scott R. GREENE*, Erik L. HEWLETT‡, Franz M. MATSCHINSKY $\dagger$ \\ and Bryan A. WOLF*1 \\ *Department of Pathology and Laboratory Medicine, Children's Hospital of Philadelphia and University of Pennsylvania School of Medicine, 5135 Main Building, 34 th \\ Street and Civic Center Blvd, Philadelphia, PA 19104-4399, U.S.A., †Department of Biochemistry and Biophysics, University of Pennsylvania School of Medicine, \\ Philadelphia, PA 19104, U.S.A., and \$Department of Medicine, University of Virginia School of Medicine, Charlottesville, VA 22908, U.S.A.
}

\begin{abstract}
Activation of protein kinase A (cAMP-dependent protein kinase; PKA) triggers insulin secretion in the $\beta$-cell. Adenylate cyclase toxin (ACT), a bacterial exotoxin with adenylate cyclase activity, and forskolin, an activator of adenylate cyclase, both dosedependently increased insulin secretion in the presence, but not the absence, of glucose in insulin-secreting $\beta$ TC3 cells. The stimulation of cAMP release by either agent was dose-dependent but glucose-independent. Omission of extracellular $\mathrm{Ca}^{2+}$ totally abolished the effects of ACT on insulin secretion and cytosolic cAMP accumulation. ACT and forskolin caused rapid and dramatic increases in cytosolic $\mathrm{Ca}^{2+}$, which were blocked by nifedipine and the omission of extracellular $\mathrm{Ca}^{2+}$. Omission of
\end{abstract}

glucose completely blocked the effects of forskolin and partially blocked the effects of ACT on cytosolic $\mathrm{Ca}^{2+}$. PKA $\alpha, \beta$ and $\gamma$ catalytic subunits ( $\mathrm{C} \alpha, \mathrm{C} \beta$ and $\mathrm{C} \gamma$ respectively) were identified in $\beta$ TC6 cells by confocal microscopy. Glucose and glucagon-like polypeptide-1 (GLP-1) caused translocation of $\mathrm{C} \alpha$ to the nucleus and of $\mathrm{C} \beta$ to the plasma membrane and the nucleus, but did not affect the distribution of $\mathrm{C} \gamma$. In conclusion, glucose and GLP-1 amplify insulin secretion via cAMP production and PKA $\beta$ activation.

Key words: adenylate cyclase, cAMP, glucose.

\section{INTRODUCTION}

The second messenger cAMP mediates diverse cellular processes, such as exocytosis, cell proliferation, ion transport, intermediate metabolism and gene transcription, by activation of the cAMPdependent protein kinase (protein kinase A; PKA) [1,2]. Activation of PKA occurs when cAMP binds to the two regulatory subunits of the tetrameric PKA holoenzyme, resulting in the release of two active catalytic subunits [3-5]. Three catalytic subunit isoforms have been identified, and designated as $\mathrm{C} \alpha, \mathrm{C} \beta$ and $\mathrm{C} \gamma$, each representing a specific gene product. $\mathrm{C} \alpha$ and $\mathrm{C} \beta$ are closely related (93\% identity), whereas $\mathrm{C} \gamma$ is $83 \%$ and $79 \%$ similar to $\mathrm{C} \alpha$ and $\mathrm{C} \beta$ respectively [6]. Four types of regulatory subunits have been identified, i.e. $\operatorname{RI} \alpha, \operatorname{RI} \beta, \operatorname{RII} \alpha$ and $\operatorname{RII} \beta$. An increase in cAMP results in translocation of PKA to the nucleus, where it may regulate gene transcription [5].

The functional role of PKA in the regulation of insulin secretion by pancreatic $\beta$-cells has been established through studies with pharmacological tools [7,8]. It is currently unclear which PKA isoforms are present in $\beta$-cells. It has been reported that type I-like and type II-like PKA regulatory subunits are present in homogenates of rat islets of Langerhans, as assessed using DEAE-cellulose ion-exchange chromatography [9]. However, their molecular masses and protein sequences are unknown, and the specific type(s) of catalytic subunits in $\beta$-cells have not been studied. The endogenous substrate(s) of PKA are also unknown [10].

PKA may be involved in the activation of insulin gene transcription by glucose, although the mechanisms of this process are still unresolved [11-14]. It has been shown that enhanced insulin gene transcription requires an increase in intracellular $\mathrm{Ca}^{2+}$ in fetal islet $\beta$-cells [15], in the murine insulinoma cell line $\beta$ TC3 [16] and in HIT-T15 cells [17], but $\mathrm{Ca}^{2+}$-dependence was not demonstrated in primary rat islets [18], HIT-T15 cells [12,19] or MIN6 cells [20]. cAMP response element binding protein (CREB) is found to be present in many cell types, and mediates cAMP-induced alterations to gene transcription $[21,22]$ by binding to the cAMP response element (CRE) of the corresponding genes. The CRE is also present in the rat insulin I gene [23]. However, in nuclear extracts of HIT cells, CREB does not bind to the CRE of the insulin gene, although it binds to the CREs of the glucagon and somatostatin genes [24]. Moreover, the stimulation of transcription by cAMP through the insulin CRE was weak in that study [24]. Thus the mechanisms of regulation of insulin transcription by glucose and glucagon-like polypeptide-1 (GLP-1), a candidate therapeutic agent for Type II diabetes [25], are still not established.

Adenylate cyclase toxin (ACT) is a single polypeptide molecule produced by Bordetella pertussis [26,27]. It is present predominantly in an extracytoplasmic location in the bacterium. ACT enters target cells and catalyses the production of cAMP, and thus activates PKA $[26,27]$. The aims of the present study were to use this pharmacological agent to investigate the mechanisms by which physiological agents stimulate insulin secretion.

\section{EXPERIMENTAL}

\section{Insulin-secreting $\boldsymbol{\beta}$-cell lines and mouse islet isolation}

The insulin-secreting mouse $\beta$-cell lines $\beta$ TC 3 and $\beta$ TC6 were maintained in culture as described previously [28]. In brief, cells

Abbreviations used: ACT, adenylate cyclase toxin; C $\alpha$ (etc.), catalytic subunit $\alpha$ (etc.); CRE, cAMP response element; CREB, cAMP response element binding protein; DMEM, Dulbecco's modified Eagle's medium; GLP-1, glucagon-like polypeptide-1; KRB, Krebs/Ringer bicarbonate buffer; m/c ratio, membrane/cytosol ratio; n/c ratio, nucleus/cytosol ratio; PKA, protein kinase A/cAMP-dependent protein kinase; Rl $\alpha$ (etc.), regulatory subunit l $\alpha$ (etc.).

1 To whom correspondence should be addressed (e-mail wolfb@mail.med.upenn.edu). 

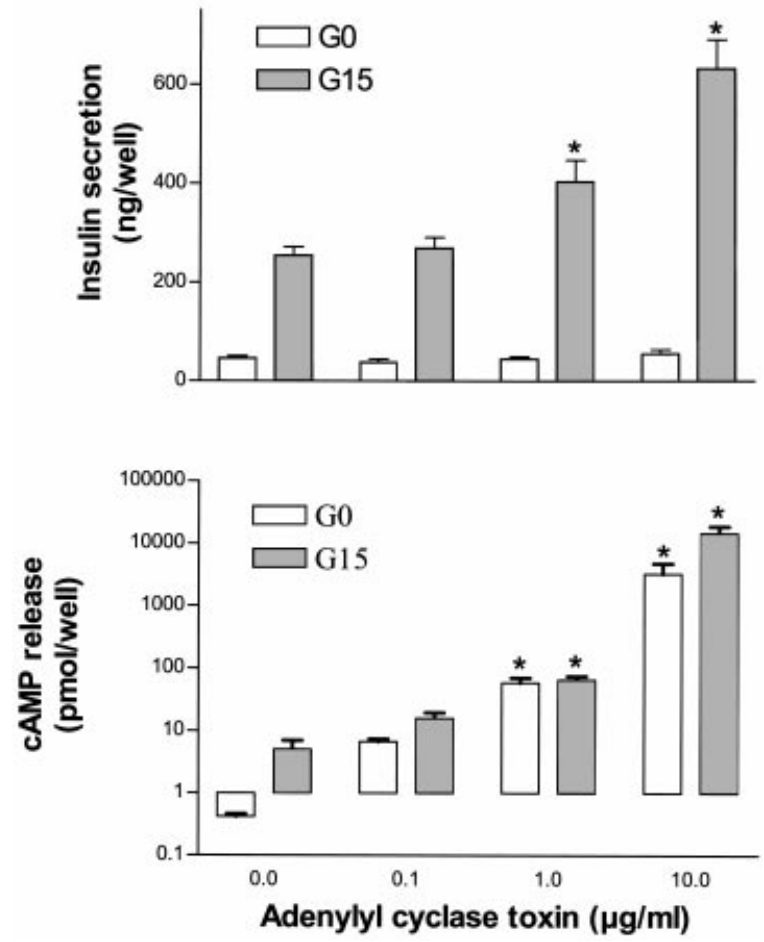

Figure 1 Effects of ACT on insulin secretion and CAMP release in $\beta$ TC3 cells

$\beta$ TC3 cells were plated in 24-well dishes and cultured in RPMI medium containing $11 \mathrm{mM}$ glucose. On the day of the experiment, $\beta$-cells were washed twice with $\mathrm{KRB}(115 \mathrm{mM} \mathrm{NaCl}$, $24 \mathrm{mM} \mathrm{NaHCO}_{3}, 5 \mathrm{mM} \mathrm{KCl}, 1 \mathrm{mM} \mathrm{MgCl}, 2.5 \mathrm{mM} \mathrm{CaCl}, 25 \mathrm{mM}$ Hepes, pH 7.4, and $0.1 \%$ BSA) containing no glucose, preincubated in the absence of glucose for $60 \mathrm{~min}$, and then incubated for another 60 min with ACT at the indicated concentrations in the absence (G0; open bars) or in the presence (G15; solid bars) of $15 \mathrm{mM}$ glucose. Results are means \pm S.E.M. for insulin secretion (upper panel) and CAMP release (lower panel) from three experiments performed in triplicate.

were maintained in RPMI 1640 medium ( $\beta$ TC3) or Dulbecco's modified Eagle's medium (DMEM) ( $\beta$ TC6) (Life Technologies, Inc., Grand Island, NY, U.S.A.) supplemented with $10 \%(\mathrm{v} / \mathrm{v})$ fetal bovine serum (Hyclone, Logan, UT, U.S.A.), 100 units $/ \mathrm{ml}$ penicillin and $50 \mu \mathrm{g} / \mathrm{ml}$ streptomycin, and incubated at $37^{\circ} \mathrm{C}$ in a humidified incubator with $5 \% \mathrm{CO}_{2} / 95 \%$ air $(\beta \mathrm{TC} 3)$ or $10 \%$ $\mathrm{CO}_{2} / 90 \%$ air ( $\beta$ TC6). Mouse islets were isolated using collagenase as described previously [29] and cultured in RPMI medium containing $11 \mathrm{mM}$ glucose for 1-2 days.

\section{Insulin secretion and cAMP measurement}

$\beta$ TC3 cells were plated in 24-well dishes and used between $50 \%$ and $70 \%$ confluence. On the day of the experiment they were washed two times with Krebs-Ringer bicarbonate buffer (KRB: $115 \mathrm{mM} \mathrm{NaCl}, 24 \mathrm{mM} \mathrm{NaHCO}, 5 \mathrm{mM} \mathrm{KCl}, 1 \mathrm{mM} \mathrm{MgCl}$, $2.5 \mathrm{mM} \mathrm{CaCl}_{2}, 25 \mathrm{mM}$ Hepes, $\mathrm{pH} 7.4$, and $0.1 \%$ BSA) containing no glucose and then preincubated with $1 \mathrm{ml}$ of $\mathrm{KRB}$ lacking glucose for $60 \mathrm{~min}$ at $37^{\circ} \mathrm{C}$. Medium was removed and cells were incubated for an additional 60 min with $1 \mathrm{ml}$ of fresh KRB containing the tested agents. Incubation buffer was taken for insulin determination by RIA using a rat insulin standard curve and a Miles antibody, and for cAMP assay with a RIA kit from Amersham Pharmacia Biotech Inc. (Piscataway, NJ, U.S.A.). Cells were washed with fresh ice-cold KRB, and intracellular cAMP was extracted with perchloric acid and

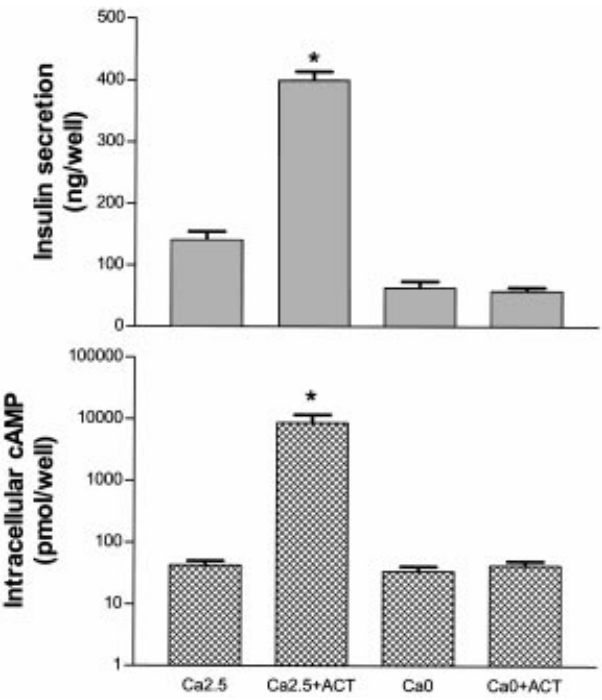

Figure $2 \mathrm{Ca}^{2+}$ dependence of stimulation by ACT of insulin secretion and cAMP content in $\beta$ TC3 cells

$\beta$-Cells were prepared as in Figure 1. ACT was used at $5 \mu \mathrm{g} / \mathrm{ml}$ in the absence (Ca0) or presence (Ca2.5) of $2.5 \mathrm{mM} \mathrm{Ca}^{2+}$ in $\mathrm{KRB}$ supplemented with $15 \mathrm{mM}$ glucose. Incubation buffer was taken for measurement of insulin, and intracellular CAMP accumulation was determined after washing the cells and extracting CAMP with ice-cold perchloric acid. Results are means \pm S.E.M. for insulin secretion (upper panel) and intracellular cAMP content (lower panel) from three experiments performed in triplicate.

measured as described above. Assays were performed in the RIA core of the Penn Diabetes Center [30].

\section{Measurement of cytosolic free $\mathrm{Ca}^{2+}$}

$\beta$ TC3 cells were plated on coverslips and cultured in RPMI containing $11 \mathrm{mM}$ glucose for 1-2 days. Mouse islets were isolated using collagenase as described previously [31] and cultured in RPMI containing $11 \mathrm{mM}$ glucose for 1-2 days. Cells or islets were then loaded with fura-2 during a 40 min pretreatment at $37^{\circ} \mathrm{C}$ in $\mathrm{KRB}$ without glucose and with $1 \mu \mathrm{M}$ fura-2 acetoxymethyl ester (Molecular Probes, Eugene, OR, U.S.A.). The coverslips with cells were mounted on a Zeiss fluorescence microscope, while the islets were fixed by slight suction on the tip of a micropipette in a chamber placed on the homeothermic platform of the microscope. Cells or islets were incubated in $\mathrm{KRB}$ at $37^{\circ} \mathrm{C}$. The microscope was used with a $40 \times$ oilimmersion objective. Fura-2 was excited successively at $334 \mathrm{~nm}$ and $380 \mathrm{~nm}$ by means of two narrow band-pass filters. The emitted fluorescence was filtered through a $520 \mathrm{~nm}$ filter, captured with an Attofluor CCD video camera at a resolution of $512 \times 480$ pixels, digitized into 256 gray levels and analysed with version 6.07 of the Attofluor RatioVision software (Atto Instruments, Rockville, MD, U.S.A.). The concentration of $\mathrm{Ca}^{2+}$ was calculated by comparing the ratio of fluorescence at each pixel with an in vitro two-point calibration curve. The $\mathrm{Ca}^{2+}$ concentration is presented by averaging the values of all pixels in an islet or in a cell. Data points were collected at intervals of $20 \mathrm{~s}$ [29].

\section{Western blot analysis of $\beta$ TC6 cells}

$\beta$ TC6 cells were plated in 10-cm dishes and cultured in DMEM. Cells were serum-starved overnight, and then washed once with glucose-free KRB and incubated with glucose-free KRB for $3 \mathrm{~h}$. 

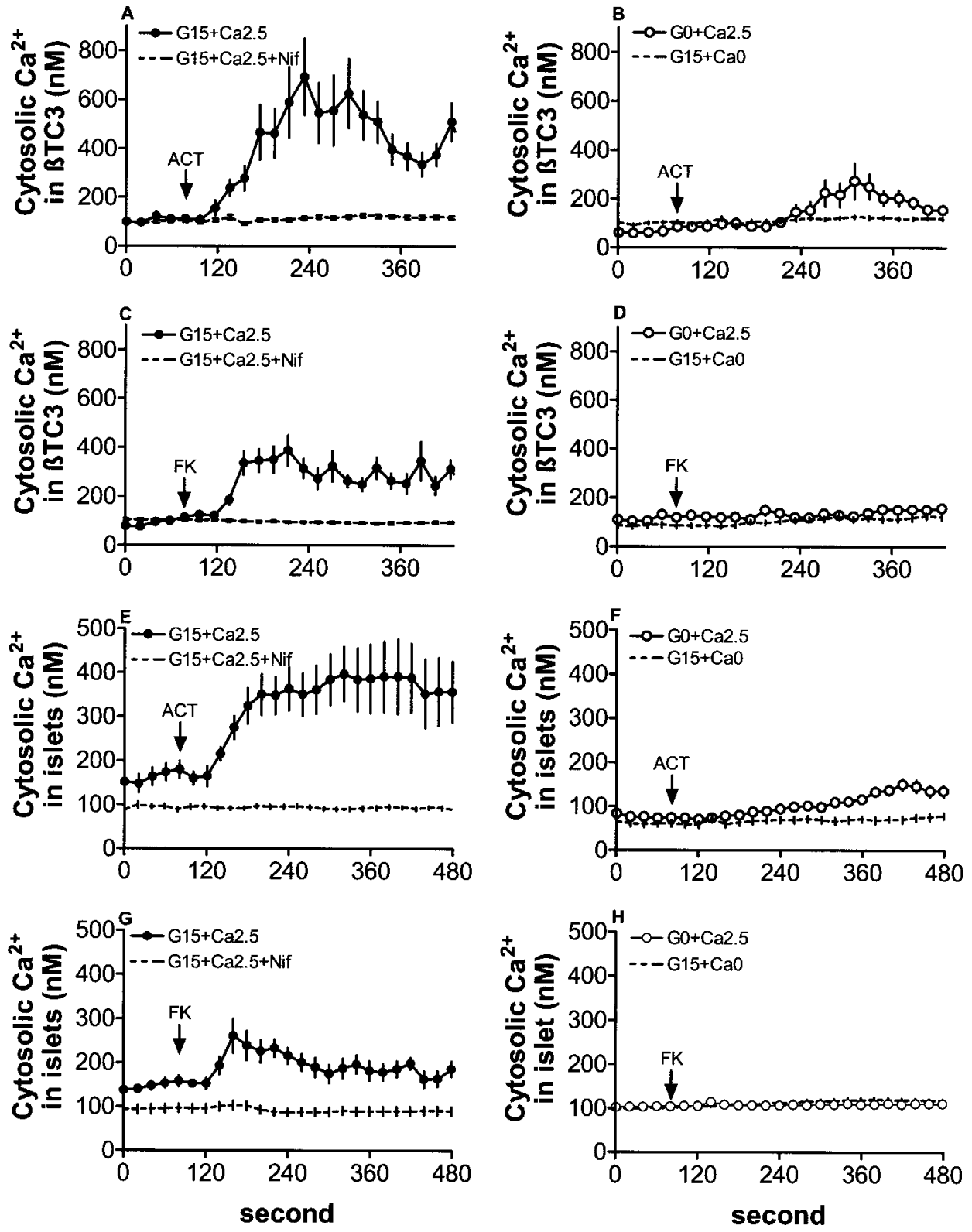

Figure 3 Effects of ACT and forskolin on cytosolic $\mathrm{Ca}^{2+}$ levels in $\beta$ TC3 cells and mouse islets

$\beta$ TC3 cells were plated on glass coverslips and cultured in RPMI medium containing $11 \mathrm{mM}$ glucose for $1-2$ days. Mouse islets were isolated as described in the Experimental section and were also cultured in the presence of $11 \mathrm{mM}$ glucose for $1-2$ days. While the $\mathrm{Ca}^{2+}$ signal was captured, $1 \mu \mathrm{g} / \mathrm{ml}$ ACT or $10 \mu \mathrm{M}$ forskolin (FK) was added to the $\beta$ TC3 cells or mouse islets with four different conditions: $15 \mathrm{mM}$ glucose and $2.5 \mathrm{mM}$ calcium (G15 + Ca2.5), $15 \mathrm{mM}$ glucose, $2.5 \mathrm{mM}$ calcium and nifedipine (G15 + Ca2.5 + Nif), no glucose and $2.5 \mathrm{mM}$ calcium (G0 + Ca2.5) or $15 \mathrm{mM}$ glucose and no calcium (G15+Ca0). Results are means \pm S.E.M. for cytosolic $\mathrm{Ca}^{2+}$ from three experiments with 58-59 cells or six islets per condition.

The cells were then incubated in fresh KRB containing various agents. Following incubation they were washed with ice-cold PBS and scraped into $0.3 \mathrm{ml}$ of fresh lysis buffer containing protease inhibitors and phosphatase inhibitors. An equal amount of protein from each incubation was analysed by SDS/PAGE and immunoblotted with an antibody recognizing a specific PKA catalytic subunit (Santa Cruz Biotechnology, Inc., Santa Cruz, CA, U.S.A.) or the phosphorylated form of CREB (Upstate Biotechnology, Lake Placid, NY, U.S.A.), followed by detection with ${ }^{125}$ I-Protein A of high specific radioactivity. The radioactivity in each band was quantified on a PhosphorImager (Molecular Dynamics) using ImageQuant software [32].

\section{Subcellular localization of PKA and CREB in $\beta$ TC6 cells}

Cells were plated on 12-mm glass coverslips and cultured in DMEM. Cells were serum-starved overnight, and then washed once with glucose-free KRB and incubated with glucose-free $\mathrm{KRB}$ for $3 \mathrm{~h}$. Cells were then incubated in fresh KRB containing various agents. After this, the cells were washed with ice-cold PBS and fixed with methanol at $-20^{\circ} \mathrm{C}$ for $15 \mathrm{~min}$. Cells were incubated with rabbit antibodies specific for a PKA catalytic subunit or with rabbit anti-CREB antibodies (Santa Cruz Biotechnology) for $1 \mathrm{~h}$, followed by washing. Fluorescently labelled anti-IgG secondary antibody (Jackson Immuno Research 


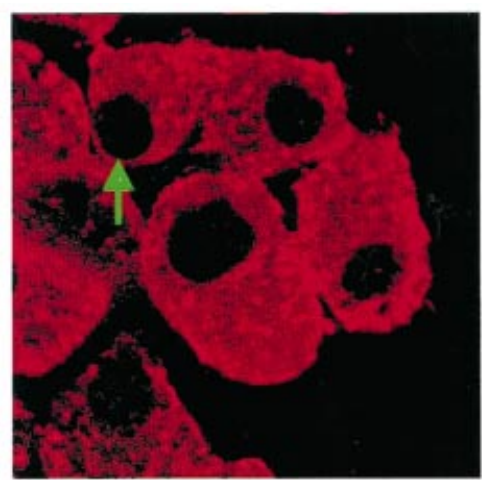

G0

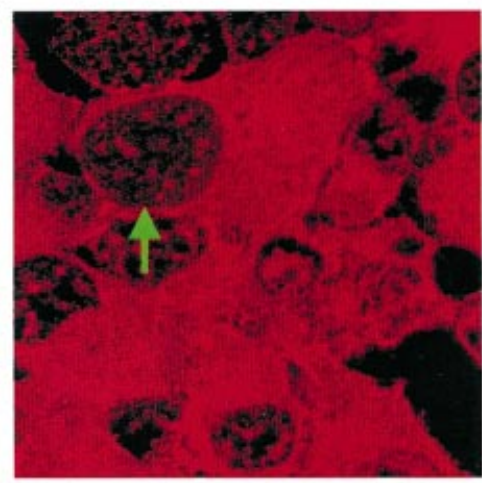

GLP

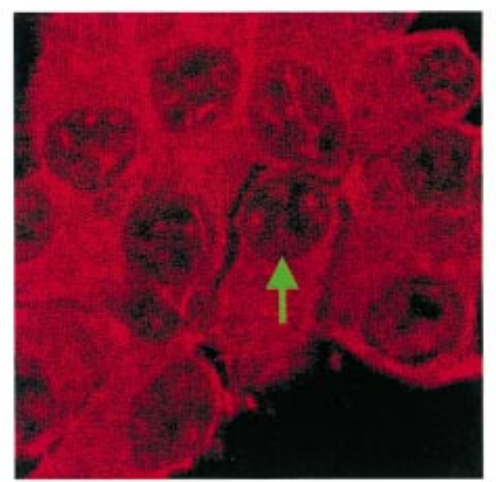

ACT

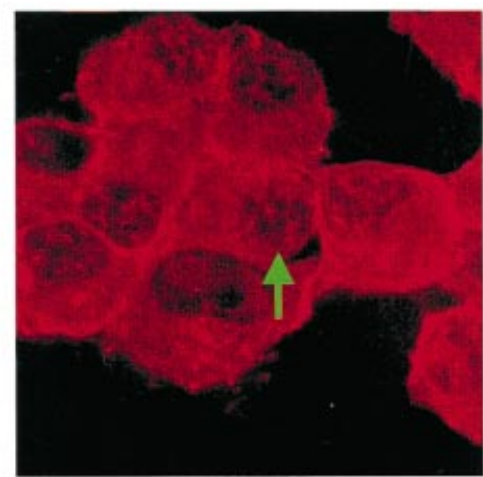

$\mathrm{G} 20 \mathrm{CCH}$

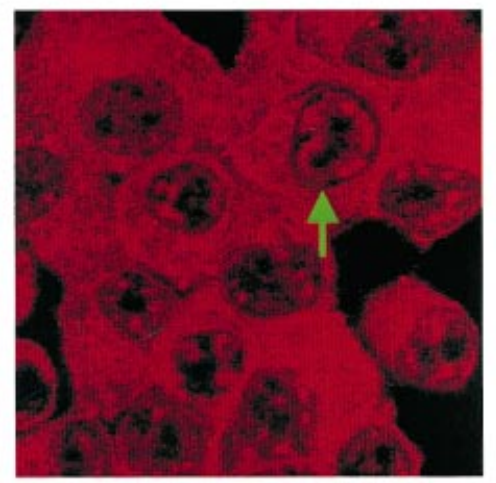

FK

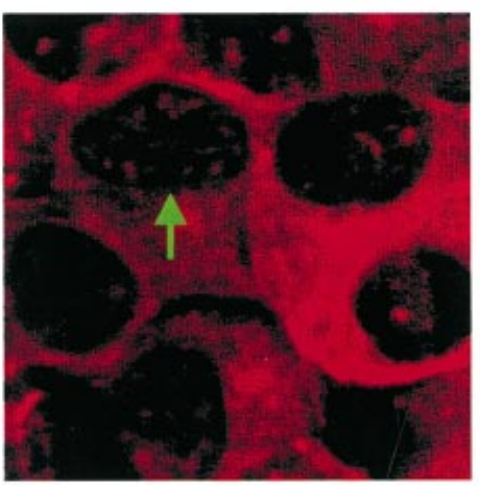

K30

Figure 4 Subcellular localization of PKA $\alpha$ in $\beta$ TC6 cells

$\beta$ TC6 cells were plated on 12-mm glass coverslips and cultured in DMEM containing $25 \mathrm{mM}$ glucose for 2-4 days. Cells were serum-starved overnight in the absence of glucose, and then incubated in KRB containing no glucose for $3 \mathrm{~h}$ before they were treated with no glucose (G0), $20 \mathrm{mM}$ glucose $+0.5 \mathrm{mM}$ carbachol (G20CCH), $100 \mathrm{nM}$ GLP-1, $10 \mu \mathrm{M}$ forskolin (FK), $1 \mu \mathrm{g} / \mathrm{ml} \mathrm{ACT} \mathrm{or} 30 \mathrm{mM}$ $\mathrm{K}^{+}$(K30) for $40 \mathrm{~min}$. Cells were washed with PBS, fixed in methanol, washed again and stained with primary and Texas Red-conjugated secondary antibodies. Cells were analysed by scanning confocal laser microscopy and transmission microscopy (to identify nuclei; denoted by arrows). Panels show representative scans from three to five experiments.

Laboratories, West Grove, PA, U.S.A.) was subsequently added for $1 \mathrm{~h}$, followed by washing. Coverslips with cells were then fixed on glass slides and the subcellular localization of PKA in cells was examined by laser scan confocal microscopy (Biomedical Imaging Core, DERC, University of Pennsylvania) [33]. Confocal images were then quantified using ImageQuant software.

\section{Data analysis}

Student's $t$ tests were performed when two groups were compared. ANOVA was used, followed by the Newman-Keuls test, when multiple groups were compared. Differences were considered significant at $P<0.05$.

\section{Materials}

Recombinant ACT was prepared from plasmid pT7ACT1 [34] using calmodulin-affinity chromatography as the final step [26]. The material was eluted and stored in buffer containing urea $(8 \mathrm{M})$, Tricine $(10 \mathrm{mM})$, EDTA $(0.5 \mathrm{mM})$ and EGTA $(0.5 \mathrm{mM})$, $\mathrm{pH} 8.0$, until use, at which time it was diluted at least 100 -fold into the medium for that experiment. All other chemicals were 
from Sigma (St. Louis, MO, U.S.A.), while molecular biological reagents were from GIBCO BRL (Grand Island, NY, U.S.A.).

\section{RESULTS}

\section{ACT stimulates insulin secretion}

ACT is a polypeptide produced by Bordetella pertussis which enters target cells and generates high levels of cAMP [35,36]. The effects of ACT on insulin secretion were first tested in the presence of $15 \mathrm{mM}$ glucose with concentrations of $0.1-$ $10 \mu \mathrm{g} / \mathrm{ml}$ ACT (Figure 1, upper panel). At a concentration of $10 \mu \mathrm{g} / \mathrm{ml}$, ACT produced a 2.5 -fold increase in glucoseinduced insulin secretion $(P<0.05$ compared with glucose alone). A 1.6-fold increase was produced by $1 \mu \mathrm{g} / \mathrm{ml}$ ACT $(P<0.05)$. On the other hand, ACT did not affect insulin secretion in the absence of glucose at any concentration tested $(P>0.05)$. An unacylated ACT, which is unable to bind and enter target cells, failed to stimulate glucose-induced insulin secretion [37]. The effects of GLP-1 on insulin secretion were also tested in incubated $\beta \mathrm{TC} 3$ cells. Basal insulin secretion was $134 \pm 11 \mathrm{ng} /$ well, which was increased by 10 and $100 \mathrm{nM}$ GLP-1 to $240 \pm 17$ and $229 \pm 11 \mathrm{ng} /$ well respectively.

The stimulation of cAMP release by ACT was also assessed. In the presence of $15 \mathrm{mM}$ glucose, ACT dose-dependently increased the release of cAMP from $\beta$ TC 3 cells. The lowest effective concentration of ACT was $1 \mu \mathrm{g} / \mathrm{ml}(P<0.05)$, which resulted in a $>100$-fold increase in cAMP levels $(58.9 \pm 11.9 \mathrm{pmol} /$ well $)$ compared with control $(0.42 \pm 0.05 \mathrm{pmol} /$ well $)$. The slope of the ACT dose-response curve for cAMP release was exponential, with an increase of five orders of magnitude at $10 \mu \mathrm{g} / \mathrm{ml}$. In the absence of glucose, the basal level of cAMP release was slightly lower than that in the presence of $15 \mathrm{mM}$ glucose. ACT alone also dose-dependently increased cAMP release, but to slightly lower levels than those obtained in the presence of glucose (Figure 1, lower panel).

The influence of extracellular $\mathrm{Ca}^{2+}$ on the effects of ACT was tested in the presence of $15 \mathrm{mM}$ glucose (Figure 2). In the presence of $2.5 \mathrm{mM}$ extracellular $\mathrm{Ca}^{2+}$ and $15 \mathrm{mM}$ glucose, ACT produced a 2.8 -fold increase in insulin secretion ( $400 \pm 14$ compared with $141 \pm 14 \mathrm{ng} /$ well; $P<0.05)$, and an increase of three orders of magnitude in the intracellular cAMP level $(P<0.05)$. The omission of extracellular $\mathrm{Ca}^{2+}$ decreased insulin secretion by $50 \%(P<0.05)$, but did not affect the intracellular cAMP level $(64 \pm 10$ compared with $59 \pm 6 \mathrm{ng} /$ well; $P>0.05)$. The absence of extracellular $\mathrm{Ca}^{2+}$ completely abolished the stimulation by ACT of insulin secretion $(P>0.05)$ and of intracellular cAMP accumulation $(P>0.05)$.

\section{cAMP-dependent regulation of cytosolic $\mathrm{Ca}^{2+}$}

The effects of ACT and forskolin on cytosolic $\mathrm{Ca}^{2+}$ were studied in $\beta$ TC 3 cells and cultured mouse pancreatic islets (Figure 3 ). In the presence of $15 \mathrm{mM}$ glucose and $2.5 \mathrm{mM}$ extracellular $\mathrm{Ca}^{2+}$, addition of $1 \mu \mathrm{g} / \mathrm{ml}$ ACT to $\beta$ TC3 cells caused a rapid and dramatic increase in cytosolic $\mathrm{Ca}^{2+}$, from $113 \pm 11 \mathrm{nM}$ to a peak level of $694 \pm 156 \mathrm{nM}(P<0.05)$ (Figure 3A). Addition of $1 \mu \mathrm{M}$ nifedipine at the start of the experiment in the presence of $15 \mathrm{mM}$ glucose did not significantly change the $\mathrm{Ca}^{2+}$ level; however, it completely blocked the effects of ACT (Figure 3A). In cultured pancreatic mouse islets, ACT increased cytosolic $\mathrm{Ca}^{2+}$ from $165 \pm 23 \mathrm{nM}$ to a peak of $391 \pm 80 \mathrm{nM}(P<0.05)$ in the presence of $15 \mathrm{mM}$ glucose and $2.5 \mathrm{mM} \mathrm{Ca}{ }^{2+}$. The cytosolic $\mathrm{Ca}^{2+}$ level in the presence of $15 \mathrm{mM}$ glucose was decreased by nifedipine, while the effect of ACT was completely blocked when $1 \mu \mathrm{M}$ nifedipine was added at the start of the experiment (Figure 3E). In the
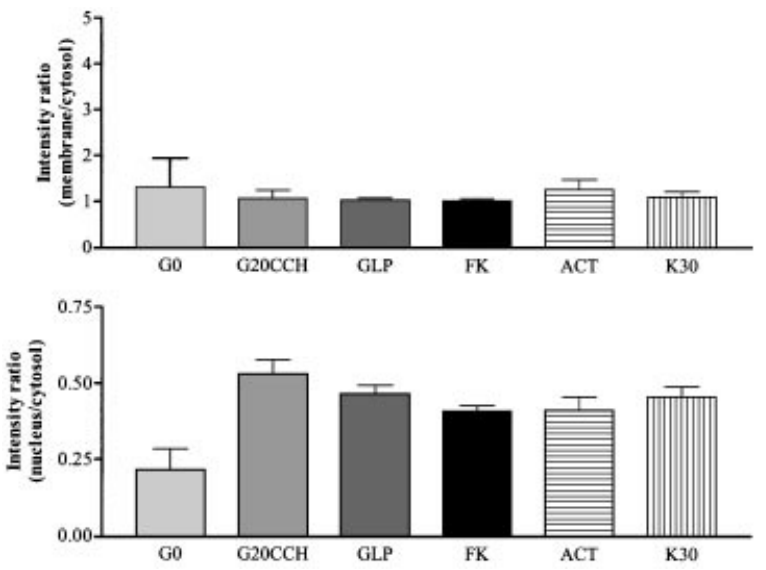

Figure 5 Quantification of the subcellular localization of PKA $\alpha$ in $\beta$ TC6 cells

Cells were incubated under the following conditions for $40 \mathrm{~min}$ : no glucose (G0), $20 \mathrm{mM}$ glucose $+0.5 \mathrm{mM}$ carbachol (G20CCH), $100 \mathrm{nM} \mathrm{GLP}-1,10 \mu \mathrm{M}$ forskolin (FK), $1 \mu \mathrm{g} / \mathrm{ml} \mathrm{ACT}$ or $30 \mathrm{mM} \mathrm{K}^{+}(\mathrm{K} 30)$. Images acquired as in Figure 4 were analysed with ImageQuant software to determine the fluorescence intensity of three cellular regions: cytosol, plasma membrane and nucleus. Intensities were then normalized by calculating the $\mathrm{m} / \mathrm{c}$ and $\mathrm{n} / \mathrm{c}$ ratios. Data are means \pm S.E.M. of $10-27$ cells.

absence of glucose and in the presence of $2.5 \mathrm{mM}$ extracellular $\mathrm{Ca}^{2+}$, ACT produced a much smaller increase in cytosolic $\mathrm{Ca}^{2+}$, from $84 \pm 14 \mathrm{nM}$ to a peak of $273 \pm 74 \mathrm{nM}(P<0.05)$, in $\beta$ TC3 cells. When extracellular $\mathrm{Ca}^{2+}$ was omitted and $1 \mathrm{mM}$ EGTA and $15 \mathrm{mM}$ glucose were present, ACT had no effect on cytosolic $\mathrm{Ca}^{2+}(P>0.05)$ in $\beta$ TC3 cells. ACT produced similarly small or no effects in mouse islets in the absence of glucose alone or in the absence of extracellular $\mathrm{Ca}^{2+}$ alone (Figure 3F).

Forskolin at $10 \mu \mathrm{M}$ produced an increase in cytosolic $\mathrm{Ca}^{2+}$, smaller than that induced by ACT, in the presence of glucose and $2.5 \mathrm{mM}$ extracellular $\mathrm{Ca}^{2+}$, from $114 \pm 15 \mathrm{nM}$ to a peak of $387 \pm 62 \mathrm{nM} \quad(P<0.05)$. Nifedipine also abolished forskolin stimulation of cytosolic $\mathrm{Ca}^{2+}$ in $\beta$ TC3 cells when added at the beginning of the experiment (Figure 3C). Similar effects of ACT and blockage by nifedipine were observed in mouse islets (Figure $3 \mathrm{G})$. Forskolin was ineffective either without glucose or without $\mathrm{Ca}^{2+}$ alone $(P>0.05)$ in both $\beta \mathrm{TC} 3$ cells and mouse islets (Figures 3D and 3H). In summary, neither ACT nor forskolin increased cytosolic $\mathrm{Ca}^{2+}$ in the presence of the $\mathrm{Ca}^{2+}$ channel blocker nifedipine. Cytosolic $\mathrm{Ca}^{2+}$ was increased by $10 \mathrm{nM}$ GLP1 to $189 \pm 16 \mathrm{nM}$, which was significantly higher than the value of $106 \pm 6 \mathrm{nM}$ under basal conditions.

\section{PKA isoforms in insulin-secreting $\boldsymbol{\beta}$-cells}

The presence of the $\mathrm{C} \alpha, \mathrm{C} \beta$ and $\mathrm{C} \gamma$ catalytic subunits of PKA in $\beta$ TC6 cells was first demonstrated by Western blot experiments. Their relative amounts were not changed by $1-3 \mathrm{~h}$ of treatment with $20 \mathrm{mM}$ glucose $+1 \mathrm{mM}$ carbachol, GLP, forskolin, ACT or $30 \mathrm{mM} \mathrm{K}^{+}$(results not shown).

The subcellular localization of PKA catalytic subunits was studied by confocal laser scanning microscopy (Figures 4-7). After overnight serum starvation and a $3 \mathrm{~h}$ incubation in the absence of glucose, $\beta$-cells were incubated under the various experimental conditions. The cell borders were easily identified by the edges in phase-contrast images and by the low background intensities in fluorescent images. The borders of the nuclei were 

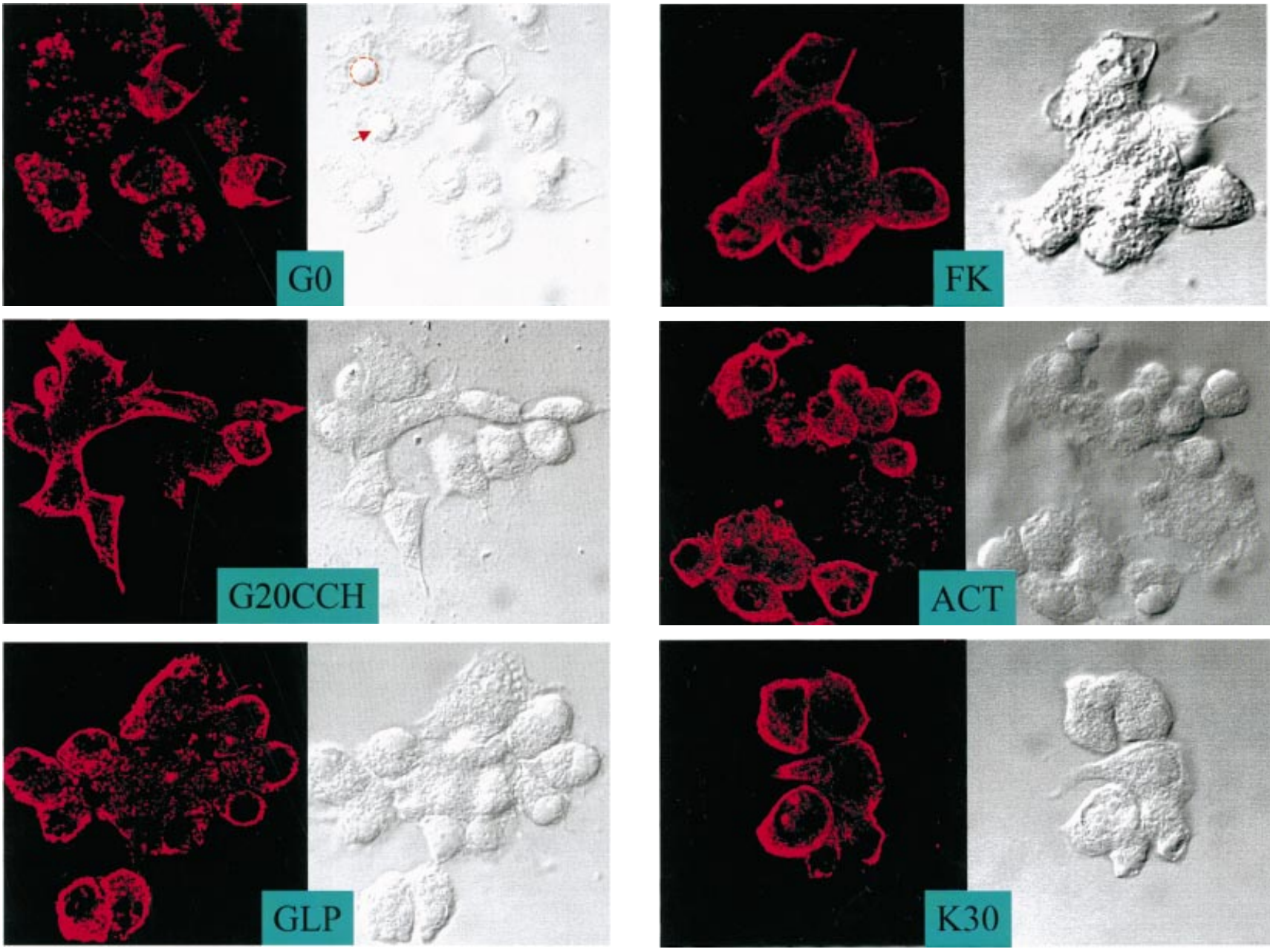

Figure 6 Subcellular localization of PKA $\beta$ in $\beta$ TC6 cells

$\beta$ TC6 cells were prepared as in Figure 4, except that an antibody to PKA $\beta$ was used. Conditions were as follows: no glucose (G0), $20 \mathrm{mM}$ glucose $+0.5 \mathrm{mM}$ carbachol (G20CCH), $100 \mathrm{nM}$ GLP-1, $10 \mu \mathrm{M}$ forskolin (FK), $1 \mu \mathrm{g} / \mathrm{ml}$ ACT and $30 \mathrm{mM} \mathrm{K}^{+}$(K30). Panels show representative scans and transmission micrographs from four experiments.

identified by the distinctive reflection of light in the phasecontrast images, as indicated by a red circle or a red arrow in Figure 6. This is probably due to the elevation of the region above the nuclei. The area inside the cell border but outside the nucleus was considered as the cytosol. For $\mathrm{C} \alpha$, the nucleus can also be easily identified in the fluorescent image because of its lower intensity of staining. However, the phase-contrast images are needed to identify the nuclei in $\mathrm{C} \beta$ images. The fluorescence intensity in three different regions of the cells was quantified using ImageQuant software, and normalized as the membrane/ cytosol $(\mathrm{m} / \mathrm{c})$ ratio and the nucleus/cytosol $(\mathrm{n} / \mathrm{c})$ ratio (Figures 5 and 7$)$.

Under basal conditions ( $0 \mathrm{mM}$ glucose), PKA $\alpha$ (Figure 4$)$ was located mainly in the cytosolic or extranuclear space, with low nuclear staining, as shown by a very low $\mathrm{n} / \mathrm{c}$ ratio of $0.22 \pm 0.02$. The nucleus was identified by confocal scanning pictures (not shown) of the same confocal planes generated with transmitted light. In cells treated with $20 \mathrm{mM}$ glucose plus carbachol $(0.53 \pm$ $0.05)$, GLP-1 $(0.47 \pm 0.03)$, forskolin $(0.41 \pm 0.02)$ or ACT $(0.41 \pm 0.05)$ for $40 \mathrm{~min}, \mathrm{C} \alpha$ had a relatively higher nuclear staining $(P<0.01)$, showing that $\mathrm{C} \alpha$ was translocated to the nucleus following treatment with insulin secretagogues. Cells treated with $30 \mathrm{mM} \mathrm{K}^{+}$also had higher staining of $\mathrm{C} \alpha$ in the nucleus
$(0.46 \pm 0.03)$. PKA $\alpha$ staining in the cytosol was not significantly different from that of the control in the absence of glucose. The $\mathrm{m} / \mathrm{c}$ ratios were all close to 1 , indicating that the fluorescence intensity on the membrane was identical with that in the cytosol (Figures 4 and 5).

The subcellular distribution of the $\mathrm{C} \beta$ catalytic subunit (Figure 6) was different from that of $\mathrm{C} \alpha$. Under basal conditions, $\mathrm{C} \beta$ staining was found mainly in the cytosol, with minimal staining in the nuclei. When cells were stimulated for 40 min with $20 \mathrm{mM}$ glucose $+1 \mathrm{mM}$ carbachol, GLP-1, forskolin, ACT or $30 \mathrm{mM}$ $\mathrm{K}^{+}$, the staining on the periphery of cells was much more intense, although some intranuclear translocation of $\mathrm{C} \beta$ was also found, as quantified in Figure 7.The fluorescent and light microscopy images were scanned in the middle of most cells, and the cell boundary was thus determined precisely. Under basal conditions (no glucose), membrane staining was about the same as that in cytosol, with an $\mathrm{m} / \mathrm{c}$ ratio of $0.88 \pm 0.16$. However, $\mathrm{m} / \mathrm{c}$ ratios were increased several-fold $(P<0.01)$ following stimulation with $20 \mathrm{mM}$ glucose $+1 \mathrm{mM}$ carbachol $(3.10 \pm 0.17)$, GLP-1 $(3.69 \pm$ $0.32)$, forskolin $(3.55 \pm 0.09)$, ACT $(2.52 \pm 0.15)$ or $30 \mathrm{mM} \mathrm{K}$ $(2.08 \pm 0.015)$. When the focal plane was moved to the top or the bottom of the cell monolayer, higher $\mathrm{C} \beta$ staining was also detected, indicating that it was translocated to the plasma 

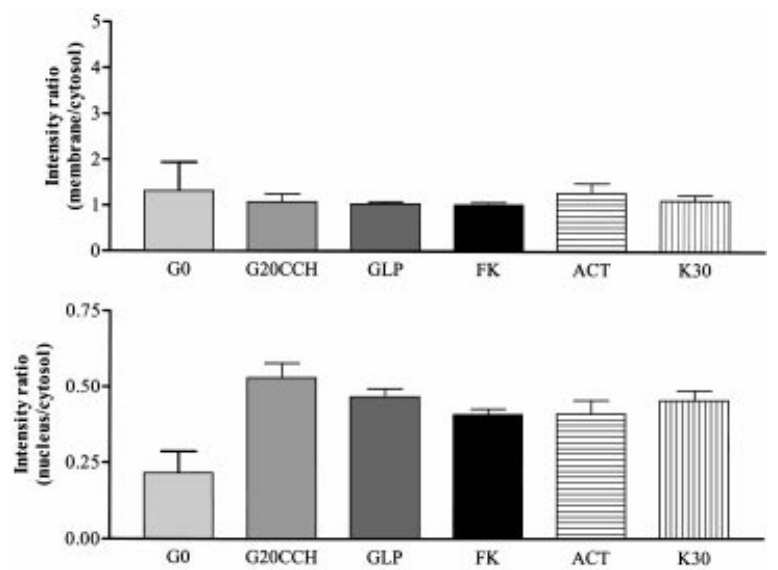

Figure 7 Quantification of the subcellular localization of PKA $\beta$ in $\beta$ TC6 cells

Cells were incubated under the following conditions for $40 \mathrm{~min}$ : no glucose (G0), $20 \mathrm{mM}$ glucose $+0.5 \mathrm{mM}$ carbachol (G20CCH), $100 \mathrm{nM}$ GLP-1, $10 \mu \mathrm{M}$ forskolin (FK), $1 \mu \mathrm{g} / \mathrm{ml}$ ACT or $30 \mathrm{mM} \mathrm{K}^{+}$(K30). Images acquired as in Figure 6 were analysed with ImageQuant software to determine the fluorescence intensity of three cellular regions: cytosol, plasma membrane and nucleus. Intensities were then normalized by calculating the $\mathrm{m} / \mathrm{c}$ and $\mathrm{n} / \mathrm{c}$ ratios. Data are means \pm S.E.M. of $8-31$ cells.

membrane and/or its vicinity. The increase in the $\mathrm{n} / \mathrm{c}$ ratio could be an artifact or could be exaggerated due to the dramatic decrease in intensity in the cytosol (Figure 7, lower panel); however, some intranuclear translocation of $\mathrm{C} \beta$ might occur.

$\mathrm{C} \gamma$ was located in both the cytosol and the nucleus, with an $\mathrm{n} / \mathrm{c}$ ratio of $0.74 \pm 0.02$ under basal conditions. Its subcellular location was not changed by the addition of forskolin, $20 \mathrm{mM}$ glucose + carbachol, GLP-1, ACT or $30 \mathrm{mM} \mathrm{K}^{+}$for $40 \mathrm{~min}$ (results not shown).

\section{DISCUSSION}

The presence of PKA in pancreatic $\beta$-cells has been known for over a decade, and its involvement in insulin secretion has been proposed in many studies $[7,8]$. However, the molecular characteristics and downstream signalling of PKA remain poorly understood. We have now identified for the first time the presence of $\alpha, \beta$ and $\gamma$ subtypes of the PKA catalytic subunit in pancreatic $\beta$-cells. It is likely that each isoform has distinct function(s) in the $\beta$-cell, based on its location. The translocation of $\mathrm{C} \beta$ from the cytosol to the plasma membrane of the $\beta$-cell suggests that substrates of PKA $\beta$ are on the plasma membrane. All cAMPstimulating agents studied (ACT, forskolin and GLP-1), or depolarization, caused translocation of $\mathrm{C} \beta$, but did not always stimulate insulin secretion if glucose was not present (ACT, forskolin and GLP); these findings suggest that $\mathrm{C} \beta$ translocation may be the cause of insulin exocytosis, but is not the consequence. Several PKA substrates on the plasma membrane have been identified in other cell systems, including voltage-dependent $\mathrm{Ca}^{2+}$ channels in cardiac microsomes [38] and ATP-sensitive K channels transfected into HEK293 cells [39]. Furthermore, in $\beta$-cells, phosphorylation of L-type Ca channels by PKA has been demonstrated by another group [40]. It is well established that the L-type $\mathrm{Ca}^{2+}$ channel is present in primary pancreatic islet $\beta$ cells and insulin-secreting $\beta$-cell lines [41]. Further evidence supportive of PKA regulation of $\mathrm{Ca}^{2+}$ channels is the observation that GLP-1 causes slower inactivation of the $\mathrm{Ca}^{2+}$ current, a prolonged burst of action potential, increased amplitude of the
$\mathrm{Ca}^{2+}$ current and thus greater $\mathrm{Ca}^{2+}$ influx into the pancreatic $\beta$ cell [42]. In the present study, activation of PKA by either ACT or forskolin amplified glucose-induced insulin secretion, which is consistent with previous studies. Activation of PKA also increased cytosolic $\mathrm{Ca}^{2+}$ levels in $\beta \mathrm{TC} 3$ cells and mouse islets in a glucose- and $\mathrm{Ca}^{2+}$-dependent manner in our present study. This effect was blocked by the L-type $\mathrm{Ca}^{2+}$ channel inhibitor nifedipine. Thus our results are compatible with the hypothesis that the L-type $\mathrm{Ca}^{2+}$ channel might be a substrate of PKA in $\beta$-cells.

Another possible substrate for PKA in $\beta$-cells is the $\mathrm{K}_{\mathrm{ATP}}$ channel. A recent report showed that the ATP-sensitive $\mathrm{K}^{+}$channel in HEK293 cells is positively regulated by PKAmediated phosphorylation of Thr-224 in the Kir6.2 subunit [39], and those authors suggested that PKA phosphorylation of this residue in Kir6.2 may be a general mechanism for regulation of $\mathrm{K}_{\mathrm{ATP}}$ channels in different tissues. A $\mathrm{K}_{\mathrm{ATP}}$ channel similar to that studied by Lin et al. [39] is also present in pancreatic $\beta$-cells. Both the Kir6.2 and SUR1 subunits of the $\mathrm{K}_{\mathrm{ATP}}$ channel contain consensus sites for PKA phosphorylation [43,44]. It can be speculated that phosphorylation of $\mathrm{K}_{\mathrm{ATP}}$ channels by PKA in $\beta$ cells could render them more sensitive to signals generated by glucose, such as the ATP/ADP ratio, and could thus potentiate depolarization and $\mathrm{Ca}^{2+}$ influx. Consistent with this view is the observation that GLP-1 inhibits $\mathrm{K}_{\mathrm{ATP}}$ channels in a glucosedependent manner in isolated rat pancreatic $\beta$-cells [45].

Following insulin secretion by the $\beta$-cell, insulin stores in the secretory granules need to be replenished. This requires regulated transcription of preproinsulin mRNA and translation of the corresponding protein. Physiological stimuli such as glucose [46] and GLP [47] are known to increase insulin mRNA levels in $\beta$ cells. The $\mathrm{C} \alpha$ and $\mathrm{C} \beta$ subunits are translocated to the nuclei and may trigger insulin transcription. The role of $\mathrm{C} \gamma$ is still unclear, since it has a relatively high intranuclear level under basal conditions and is not translocated after stimulation. However, further studies in other $\beta$-cell types and primary islet $\beta$-cells will be needed, since there might be differences between transformed cell lines and primary cells. The possibility cannot be excluded that the distribution and/or functions of PKA catalytic subunits vary between $\beta$ TC6 cells and primary $\beta$-cells. Although $\mathrm{cAMP}$ release is increased by ACT or forskolin, the physiological significance of this is currently unknown.

It has been suggested that isoenzymes of PKA with specific subcellular locations mediate distinct effects of cAMP, which are determined by the regulatory subunit (type I or type II). However, the type I PKA isoenzymes are generally soluble and cytosolic ([48]; see also [48a]), which would allow them to regulate all activities in the cytoplasm that are triggered by cAMP. Our study has demonstrated a novel mechanism of isoenzyme $(\mathrm{C} \alpha$ versus $\mathrm{C} \beta$ ) specificity via distinct patterns of translocation (nucleus versus plasma membrane), which are determined by the catalytic subunits instead of the regulatory subunits. The high content of intranuclear PKA $\gamma$ under both basal and stimulated conditions is in agreement with a previous report $[48,48 \mathrm{a}]$.

This study was supported by NIH grants DK43354, DK49814 and Al18000. The Diabetes Endocrinology Research Center (DERC) is supported by DK 19525. We are grateful to Mary Gray and Candace Hamm for help in preparing and testing the ACT.

\section{REFERENCES}

1 MacDougald, O. A. and Lane, M. D. (1995) Transcriptional regulation of gene expression during adipocyte differentiation. Annu. Rev. Biochem. 64, 345-373

2 Taylor, S. S., Buechler, J. A. and Yonemoto, W. (1990) cAMP-dependent protein kinase: framework for a diverse family of regulatory enzymes. Annu. Rev. Biochem. 59, 971-1005 
3 Skalhegg, B. S. and Tasken, K. (2000) Specificity in the cAMP/PKA signaling pathway. Differential expression, regulation, and subcellular localization of subunits of PKA. Front. Biosci. 5, D678-D693

4 Edwards, A. S. and Scott, J. D. (2000) A-kinase anchoring proteins: protein kinase A and beyond. Curr. Opin. Cell Biol. 12, 217-221

5 Daniel, P. B., Walker, W. H. and Habener, J. F. (1998) Cyclic AMP signaling and gene regulation. Annu. Rev. Nutr. 18, 353-383

6 Gamm, D. M., Baude, E. J. and Uhler, M. D. (1996) The major catalytic subunit isoforms of cAMP-dependent protein kinase have distinct biochemical properties in vitro and in vivo. J. Biol. Chem. 271, 15736-15742

7 Malaisse, W. J., Garcia-Morales, P., Dufrane, S. P., Sener, A. and Valverde, I. (1984) Forskolin-induced activation of adenylate cyclase, cyclic adenosine monophosphate production and insulin release in rat pancreatic islets. Endocrinology $\mathbf{1 1 5}$ 2015-2020

8 Holz, G. G., Leech, C. A. and Habener, J. F. (1995) Activation of a cAMP-regulated $\mathrm{Ca}(2+)$-signaling pathway in pancreatic beta-cells by the insulinotropic hormone glucagon-like peptide-1. J. Biol. Chem. 270, 17749-17757

9 Sugden, M. C., Ashcroft, S. J. and Sugden, P. H. (1979) Protein kinase activities in rat pancreatic islets of Langerhans. Biochem. J. 180, 219-229

10 Jones, P. M. and Persaud, S. J. (1998) Protein kinases, protein phosphorylation, and the regulation of insulin secretion from pancreatic beta-cells. Endocr. Rev. 19, $429-461$

11 Furukawa, N., Shirotani, T., Araki, E., Kaneko, K., Todaka, M., Matsumoto, K. Tsuruzoe, K., Motoshima, H., Yoshizato, K., Kishikawa, H. and Shichiri, M. (1999) Possible involvement of atypical protein kinase C (PKC) in glucose-sensitive expression of the human insulin gene: DNA-binding activity and transcriptional activity of pancreatic and duodenal homeobox gene-1 (PDX-1) are enhanced via calphostin C-sensitive but phorbol 12-myristate 13-acetate (PMA) and Go 6976insensitive pathway. Endocr. J. 46, 43-58

12 Goodison, S., Kenna, S. and Ashcroft, S. J. (1992) Control of insulin gene expression by glucose. Biochem. J. 285, 563-568

13 Skoglund, G., Hussain, M. A. and Holz, G. G. (2000) Glucagon-like peptide 1 stimulates insulin gene promoter activity by protein kinase A-independent activation of the rat insulin I gene cAMP response element. Diabetes 49, 1156-1164

14 Ohneda, K., Ee, H. and German, M. (2000) Regulation of insulin gene transcription. Semin. Cell Dev. Biol. 11, 227-233

15 German, M. S. and Wang, J. (1994) The insulin gene contains multiple transcriptional elements that respond to glucose. Mol. Cell. Biol. 14, 4067-4075

16 Efrat, S., Surana, M. and Fleischer, N. (1991) Glucose induces insulin gene transcription in a murine pancreatic $\beta$-cell line. J. Biol. Chem. 266, 11141-11143

17 Leibiger, I. B., Leibiger, B., Moede, T. and Berggren, P. O. (1998) Exocytosis of insulin promotes insulin gene transcription via the insulin receptor/PI-3 kinase/p70 s6 kinase and CaM kinase pathways. Mol. Cell 1, 933-938

18 De Vargas, L. M., Sobolewski, J., Siegel, R. and Moss, L. G. (1997) Individual $\beta$ cells within the intact islet differentially respond to glucose. J. Biol. Chem. 272, 26573-26577

19 Eckert, B., Schwaninger, M. and Knepel, W. (1996) Calcium-mobilizing insulin secretagogues stimulate transcription that is directed by the cyclic adenosine $3^{\prime}, 5^{\prime}$ monophosphate calcium response element in a pancreatic islet $\beta$-cell line. Endocrinology 137, 225-233

20 Kennedy, H. J., Rafiq, I., Pouli, A. E. and Rutter, G. A. (1999) Glucose enhances insulin promoter activity in MIN6 beta-cells independently of changes in intracellular $\mathrm{Ca} 2+$ concentration and insulin secretion. Biochem. J. 342, 275-280

21 Comb, M., Birnberg, N. C., Seasholtz, A., Herbert, E. and Goodman, H. M. (1986) A cyclic AMP- and phorbol ester-inducible DNA element. Nature (London) $\mathbf{3 2 3}$ 353-356

22 Ruppert, S., Cole, T. J., Boshart, M., Schmid, E. and Schutz, G. (1992) Multiple mRNA isoforms of the transcription activator protein CREB: generation by alternative splicing and specific expression in primary spermatocytes. EMBO J. 11, 1503-1512

23 Philippe, J. and Missotten, M. (1990) Functional characterization of a cAMPresponsive element of the rat insulin I gene. J. Biol. Chem. 265, 1465-1469

24 Diedrich, T. and Knepel, W. (1995) Interaction of the transcription factor CREB with pancreatic islet cell-specific enhancer elements. Biol. Chem. Hoppe Seyler 376, 39-44

25 Holz, G. G. and Habener, J. F. (1992) Signal transduction crosstalk in the endocrine system: Pancreatic $\beta$-cells and the glucose competence concept. Trends Biochem. Sci. 17, 388-393

26 Gray, M., Szabo, G., Otero, A. S., Gray, L. and Hewlett, E. (1998) Distinct mechanisms for $\mathrm{K}+$ efflux, intoxication, and hemolysis by Bordetella pertussis $\mathrm{AC}$ toxin. J. Biol. Chem. 273, 18260-18267

Received 27 June 2002; accepted 15 August 2002

Published as BJ Immediate Publication 15 August 2002, DOI 10.1042/BJ20020999
27 Hewlett, E. L. and Gray, M. C. (2000) Adenylate cyclase toxin from Bordetella pertussis. In Handbook of Experimental Pharmacology: Bacterial Protein Toxins (Aktories, K. and Just, I., eds.), pp. 473-488, Springer-Verlag, Berlin

28 Xu, G. G., Gao, Z. Y., Borge, P. D. Jr. and Wolf, B. A. (1999) Insulin receptor substrate 1-induced inhibition of endoplasmic reticulum $\mathrm{Ca}^{2+}$ uptake in beta-cells. Autocrine regulation of intracellular $\mathrm{Ca}^{2+}$ homeostasis and insulin secretion. J. Biol. Chem. 274, 18067-18074

29 Gao, Z. Y., Konrad, R. J., Collins, H., Matschinsky, F. M., Rothenberg, P. L. and Wolf, B. A. (1996) Wortmannin inhibits insulin secretion in pancreatic islets and $\beta$-TC3 cells independent of its inhibition of phosphatidylinositol 3-kinase. Diabetes 45, 854-862

30 Rothenberg, P. L., Willison, L. D., Simon, J. and Wolf, B. A. (1995) Glucose-induced insulin receptor tyrosine phosphorylation in insulin-secreting beta-cells. Diabetes $\mathbf{4 4}$ 802-809

31 Gao, Z. Y., Li, G., Najafi, H., Wolf, B. A. and Matschinsky, F. M. (1999) Glucose regulation of glutaminolysis and its role in insulin secretion. Diabetes $\mathbf{4 8}, 1535-1542$

32 Konrad, R. J., Young, R. A., Record, R. D., Smith, R. M., Butkerait, P., Manning, D., Jarett, L. and Wolf, B. A. (1995) The heterotrimeric G-protein $G_{i}$ is localized to the insulin secretory granules of $\beta$-cells and is involved in insulin exocytosis. J. Biol. Chem. 270, 12869-12876

33 Gao, Z., Reavey-Cantwell, J., Young, R. A., Jegier, P. and Wolf, B. A. (2000) Synaptotagmin III/VII isoforms mediate $\mathrm{Ca}^{2+}$-induced insulin secretion in pancreatic islet beta-cells. J. Biol. Chem. 275, 36079-36085

34 Sebo, P., Glaser, P., Sakamoto, H. and Ullmann, A. (1991) High-level synthesis of active adenylate cyclase toxin of Bordetella pertussis in a reconstructed Escherichia coli system. Gene 104, 19-24

35 Hewlett, E. L., Urban, M. A., Manclark, C. R. and Wolff, J. (1976) Extracytoplasmic adenylate cyclase of Bordetella pertussis. Proc. Natl. Acad. Sci. U.S.A. 73, 1926-1930

36 Szabo, G., Gray, M. C. and Hewlett, E. L. (1994) Adenylate cyclase toxin from Bordetella pertussis produces ion conductance across artificial lipid bilayers in a calcium- and polarity-dependent manner. J. Biol. Chem. 269, 22496-22499

37 Hackett, M., Guo, L., Shabanowitz, J., Hunt, D. F. and Hewlett, E. L. (1994) Internal lysine palmitoylation in adenylate cyclase toxin from Bordetella pertussis. Science 266, $433-435$

38 Yoshida, A., Takahashi, M., Nishimura, S., Takeshima, H. and Kokubun, S. (1992) Cyclic AMP-dependent phosphorylation and regulation of the cardiac dihydropyridinesensitive Ca channel. FEBS Lett. 309, 343-349

39 Lin, Y. F., Jan, Y. N. and Jan, L. Y. (2000) Regulation of ATP-sensitive potassium channel function by protein kinase A-mediated phosphorylation in transfected HEK293 cells. EMBO J. 19, 942-955

40 Leiser, M. and Fleischer, N. (1996) cAMP-dependent phosphorylation of the cardiactype $\alpha 1$ subunit of the voltage-dependent $\mathrm{Ca}^{2+}$ channel in a murine pancreatic $\beta$-cell line. Diabetes 45, 1412-1418

41 Henquin, J. C., Jonas, J. C. and Gilon, P. (1998) Functional significance of $\mathrm{Ca}^{2+}$ oscillations in pancreatic beta cells. Diabetes Metab. 24, 30-36

42 Gromada, J., Holst, J. J. and Rorsman, P. (1998) Cellular regulation of islet hormone secretion by the incretin hormone glucagon-like peptide 1. Pflugers Arch. 435, $583-594$

43 Inagaki, N., Gonoi, T., Clement, IV, J. P., Namba, N., Inazawa, J., Gonzalez, G. X., Aguilar-Bryan, L., Seino, S. and Bryan, J. (1995) Reconstitution of IKATP: an inward rectifier subunit plus the sulfonylurea receptor. Science 270, 1166-1170

44 Inagaki, N., Gonoi, T., Clement, J. P., Wang, C. Z., Aguilar-Bryan, L., Bryan, J. and Seino, S. (1996) A family of sulfonylurea receptors determines the pharmacological properties of ATP-sensitive $K^{+}$channels. Neuron 16, 1011-1017

45 Holz, G. G., Kühtreiber, W. M. and Habener, J. F. (1993) Pancreatic beta-cells are rendered glucose-competent by the insulinotropic hormone glucagon-like peptide1(7-37). Nature (London) 361, 362-365

46 Schuit, F. C. and Pipeleers, D. G. (1985) Regulation of adenosine $3^{\prime}, 5^{\prime}$ monophosphate levels in the pancreatic B cell. Endocrinology 117, 834-840

47 Mojsov, S., Weir, G. C. and Habener, J. F. (1987) Insulinotropin: glucagon-like peptide I (7-37) co-encoded in the glucagon gene is a potent stimulator of insulin release in the perfused rat pancreas. J. Clin. Invest. 79, 616-619

48 Hansson, V., Skalhegg, B. S. and Tasken, K. (1999) Cyclic-AMP-dependent protein kinase (PKA) in testicular cells. Cell specific expression, differential regulation and targeting of subunits of PKA. J. Steroid Biochem. Mol. Biol. 69, 367-378

48a Hansson, V., Skalhegg, B. S. and Tasken, K. (2000) Erratum and republication. J. Steroid Biochem. Mol. Biol. 73, 81-92 